\title{
MAKNA BEBAN DAN SUMBER DUKUNGAN KELUARGA DALAM MERAWAT ANAK AUTIS: STUDI FENOMENOLOGI
}

\author{
Dinarti \\ Universitas Islam Negri Syarif Hidayatullah, Jakarta 15421, Indonesia \\ E-mail:din_rh@yahoo.co.id
}

\begin{abstract}
ABSTRAK
Autisme didefinisikan sebagai suatu gangguan perkembangan yang kompleks menyangkut komunikasi, interaksi sosial, dan aktivitas imajinasi. Anak penyandang autis mempunyai masalah gangguan dalam bidang komunikasi, interaksi sosial, sensoris, pola bermain, perilaku, dan emosi. Orangtua yang memiliki anak penyandang autis pasti tampak berbeda dari orangtua lainnya. Keberadaan anak autis dengan perilakunya di dalam keluarga menimbulkan stressor tersendiri bagi setiap anggota keluarganya. Tujuan penelitian: menguraikan secara mendalam pengalaman keluarga tentang beban dan sumber dukungan keluarga serta makna dalam merawat anak autis. Metode: Desain penelitian metode kualitatif dengan pendekatan fenomenologi. Teknik pengambilan partisipan dilakukan secara purposive sampling. Sebanyak enam partisipan berpartisipasi pada penelitian ini. Pengumpulan data dilakukan dengan cara teknik wawancara mendalam (indepth interview) dan menggunakan catatan lapangan (field note). Hasil wawancara mendalam dan catatan lapangan dianalisis menggunakan metode Colaizzi. Hasil: hasil penelitian penelitian mengidentifikasi tujuh tema, yaitu beban psikologis, beban finansial, dukungan sosial, dukungan keluarga, perhatian tanpa pamrih, kecewa terhadap pemberi dukungan, dan takdir. Diskusi: Rekomendasi penelitian adalah perawat dapat meningkatkan kompetensi dalam melakukan pengkajian terhadap kebutuhan keluarga dalam merawat klien dengan autis sehingga semakin tepat dalam memberikan intervensi kepada keluarga terutama untuk meningkatkan kemampuan dan meminimalkan beban yang dirasakan keluarga anak dengan autis.
\end{abstract}

Kata Kunci: anak autis, keluarga, beban, sumber dukungan.

\section{ABSTRACT}

Autism is defined as a complex developmental disorder that includes communication, social interaction and imaginative activities. Children with autism have problems in communication, social interaction, sensory processing disorder, play patterns, behaviors and emotions. Parents who have a child with autism will be different from the other parents in every aspect. The existence of a child with autism and his/her behavior are stressor for each member of the family. Objectives: This study is aimed at explain in depth about family's experience of burden and source of support and their significance family in caring for children with autism. Methods: This study employed qualitative method with phenomenological approach. Six participants were taken using purposive sampling. Data were collected through in-depth interviews and using field notes. The results of in-depth interviews and field notes were analyzed using Colaizzi's method. Results: The results of the study identified seven themes, namely psychological burden, financial burden, social support, family support, selfless attention, disappointment over support giver, and destiny. Discussion: This study recommends that nurses improve their competence in assessing the needs of family in caring for clients with autism. So that they will provide interventions more precisely to family, particularly to increase competence and to minimize the burden carried by families of children with autism

Keywords: children with autism, family, burden, source of support. 


\section{PENDAHULUAN}

Kehadiran anak merupakan saat yang ditunggu dan menggembirakan bagi kebanyakan pasangan suami istri. Kehadiran anak tidak saja mempererat tali cinta pasangan suami istri, tetapi juga sebagai penerus generasi yang sangat diharapkan oleh keluarga tersebut. Anak tentunya akan melalui masa tumbuh kembang dalam rentang waktu kehidupannya. Seorang anak dikatakan tumbuh dapat dilihat dari perubahan fisik yang dapat diukur secara kuantitas dari masa ke masa dan dari satu peringkat ke peringkat berikutnya dan perkembangan dapat dilihat dari perubahan secara kualitas dengan membandingkan sifat terdahulu dengan sifat yang sudah terbentuk (Papalia, 2008). Proses pertumbuhan dan perkembangan yang dilalui setiap anak tidak sama dan memiliki keunikan masingmasing. Permasalahan yang dihadapi juga berbeda-beda dari satu anak ke anak yang lain. Permasalahan yang muncul pada perkembangan anak dapat berupa gangguan pada tahap perkembangan fisik, gangguan bahasa, gangguan emosi maupun gangguan sensoris motorik.

Gangguan perkembangan yang terjadi pada anak dan merupakan gangguan perkembangan yang cukup serius ialah masalah autisme. Autis bukanlah suatu penyakit, melainkan suatu gangguan perkembangan pada anak yang gejalanya tampak sebelum anak mencapai usia tiga tahun. Gejalanya sudah ada sejak lahir, tetapi sering kali luput dari perhatian orangtua (Sutadi, 2007).

Anak-anak yang mengalami gangguan autisme menunjukkan gejala kurang merespons orang lain, mengalami kendala berat dalam kemampuan komunikasi, dan memunculkan respons yang aneh terhadap berbagai aspek lingkungan di sekitarnya. Anak yang mengalami gangguan autisme ini menunjukkan kegagalan membina hubungan interpersonal yang ditandai dengan kurangnya respons dan atau kurangnya minat kepada orang-orang atau anak-anak di sekitarnya. Anak autis terlihat lebih suka menyendiri, asyik dengan dirinya sendiri, perhatiannya hanya tertuju pada satu objek yang sedang dimainkannya, dan tidak peduli dengan kejadian-kejadian di sekitarnya. Anak juga kurang mampu melakukan kontak mata dengan ibu atau ayahnya. Jika nama anak tersebut dipanggil, seolah-olah anak tidak mendengarnya dan jika anak diajak bicara, sering kali malah anak tidak menatap mata orang yang mengajaknya bicara. Anak juga kurang mampu menunjukkan respons ekspresi wajah yang wajar seperti tertawa atau tersenyum ketika digelitik atau diajak bermain oleh kedua orangtuanya (Safaria, 2005).

Peningkatan jumlah anak autis juga terjadi di Indonesia. Belum ada angka pasti tentang berapa sebenarnya jumlah anak autisme di Indonesia, tetapi pemerintah merilis data jumlah anak penyandang autisme bisa berada pada kisaran 112 ribu jiwa. Angka tersebut diasumsikan dengan prevalensi autisme pada anak yang ada di Hongkong, yaitu 1,68 per 1.000 untuk anak di bawah 15 tahun. Pemerintah menghitung dengan asumsi prevalensi autisme yang ada di Hongkong, yakni jumlah anak usia 5-19 tahun di Indonesia mencapai 66.000.805 menurut data penelitian Badan Pusat Statistik (BPS, 2013). Peningkatan penyandang autis tidak diikuti dengan peningkatan penanganan dan pendataan yang maksimal dari pemerintah.

Secara umum, dampak yang dirasakan oleh keluarga yang mempunyai anggota keluarga dengan autis adalah tingginya beban ekonomi, beban emosi, stres terhadap perilaku pasien, gangguan dalam melaksanakan kegiatan rumah tangga sehari-hari dan keterbatasan melakukan aktivitas sosial (WHO, 2001). Terlebih lagi ada 
stigma masyarakat terhadap anak dengan autis. Beban sosial ekonomi yang dimaksud meliputigangguan dalam hubungan keluarga, keterbatasan melakukan aktivitas sosial, pekerjaan dan hobi, kesulitan finansial, dan dampak negatif terhadap kesehatan fisik keluarga. Sementara itu, yang termasuk beban psikologis meliputi dampak psikologis seperti perasaan kehilangan, sedih, cemas dan malu terhadap masyarakat sekitar, stres menghadapi gangguan perilaku, dan frustrasi akibat perubahan pola interaksi dalam keluarga. Oleh karenanya, keluarga harus mencari berbagai sumber dukungan, termasuk untuk membiayai pengobatan anggota keluarga yang mengalami autis. Dukungan yang cukup terhadap keluarga akan membantu keluarga dalam merawat anak dengan autis.

Orangtua akan mengalami kecemasan dalam menghadapi anak yang autis. Orangtua pasti memiliki reaksi emosional serta sikap yang berbeda-beda. Yang sering terjadi ialah perasaan tidak percaya, marah, sedih, dan bingung serta tidak dapat menerima dengan harapan bahwa diagnosis tersebut salah. Orangtua yang mengetahui anaknya didiagnosis autis akan berusaha mengupayakan untuk membantu kesembuhan anaknya, tetapi masih ada orangtua yang belum menerima kenyataan bahwa anaknya didiagnosis mengalami gangguan autis (Priyatna, 2011).

Sekolah Autis Cipta Anugrah merupakan suatusaranapelayananpendidikanbagianakanak berkebutuhan khusus (autis). Sekolah ini didirikan dan disahkan pada 25 Juli 2008. Sekolah Autis Cipta Anugrah merupakan wadah pendidikan bagi anak berkebutuhan khusus (autis) untuk mengembangkan potensi dan bakat yang dimiliki sebagai bekal kehidupan yang mandiri. Sekolah ini menyediakan fasilitas dan prasarana yang lengkap, profesional, dan berkualitas agar dapat mengembangkan berbagai aspek kehidupannya, baik aspek intelektual, fisik, sosial, maupun keterampilan. Murid di Sekolah Autis Cipta Anugrah berjumlah 20 orang. Usia murid berkisar antara 5 sampai 20 tahun.

Berdasarkan hasil penelitian yang dilakukan oleh Fernando (2011) di Indonesia, rasio anak autis adalah 1:250 artinya ada satu juta penyandang autis di Indonesia. Data Departemen Pendidikan Nasional untuk wilayah Jakarta dan sekitarnya menunjukkan sebanyak 1.700 orang penyandang autis atau hanya sekitar setengah dari penyandang autis yang mengikuti layanan pendidikan khusus (sekolah khusus penyandang autis).

Tulisan ini melaporkan pengalaman keluarga dalam merawat anak dengan autis di Sekolah Autis Cipta Anugrah Cipayung, Jakarta Timur.

\section{METODE PENELITIAN}

Rancangan pada penelitian ini ialah rancangan kualitatif dengan pendekatan fenomenologi. Sebanyak 6 keluarga yang merawat anak autis yang bersekolah di Sekolah Autis Cipta Anugrah Cipayung Jakarta Timur adalah partisipan yang berpartisipasi pada penelitian ini. Kriteria partisipan diseleksi melalui proses rekrutmen dengan metode purposive sampling, yaitu peneliti sengaja memilih partisipan karena dianggap mempunyai karakteristik tertentu, yang dapat memperkaya data penelitian. Pengambilan data pada penelitian ini dilaksanakan pada bulan Juli-November 2015.

\section{Pengumpulan data}

Teknik pengumpulan data pada penelitian ini menggunakan wawancara mendalam yang dilakukan oleh peneliti sendiri sebagai instrumen utama peneliti dibantu dengan alat bantu kamera digital, panduan wawancara, dan field one (catatan lapangan). Sebagai alat utama, kemampuan 
melakukan wawancara yang baik sangatlah penting karena kemampuan wawancara yang baik akan menghasilkan data yang kaya (Irawan, 2006). Pengumpulan data dilakukan di rumah atau di sekolah sesuai kesepakatan dengan partisipan. Selanjutnya, data dianalisis dengan metode Collaizi, Giorgi, dan van Kam (Polit \& Beck, 2004). Peneliti memilih metode Collaizi karena metode ini memberikan langkah-langkah yang sederhana, jelas, dan rinci.

\section{HASIL DAN PEMBAHASAN}

Partisipan dalam penelitian ini berasal dari enam keluarga anak autis. Secara umum, partisipan adalah keluarga inti pasien, yaitu ibu. Usia partisipan termuda 38 tahun dan tertua 59 tahun. Tingkat pendidikan partisipan 50 persen adalah tamatan Sekolah Menengah Atas, umur anak autis termuda adalah 7 tahun dan tertua 12 tahun. Seluruh partisipan merawat anggota keluarga dengan anak autis.

Karakteristik partisipan yang peneliti paparkan di sini adalah usia, agama, suku, pendidikan terakhir, pekerjaan, status perkawinan, dan lama merawat.

Dari 6 partisipan didapatkan tema sebagai berikut.

1. Beban psikologis

Hasil penelitian menyatakan bahwa semua partisipan merasakan beban psikologis yang dinyatakan oleh partisipan dalam bentuk rasa kecewa karena anak autis bermasalah dalam komunikasi dan rasa takut terhadap perilaku anak. Selama berinteraksi dengan anak autis, partisipan merasakan kekecewaan yang disebabkan hambatan dalam berkembangan. Perasaan negatif karena perilaku yang dilakukan anak autis membuat keluarga merasa sedih dan perasaan keluarga yang lebih emosional.
“... Teristimewa dukanya karena bagi kami, anak yang menderita autis memiliki sikap, tingkah laku diatas anak normal lainnya. Oleh sebab itu, kami sebagai orangtua harus mempunyai kesabaran yang ekstra." (partisipan 1)

“... Kalau dukanya, ya kalau anaknya rewel kemauannya, tapi kita nggak tau keinginannya karena anaknya gak ngomong, dia tidak bisa ungkapin apa yang di mauin ya kita jadi sedih." (partisipan 6)

".... Pengalaman yang sangat mengganggu hidup kami adalah lingkungan di mana kami tinggal tidak bisa menerima kondisi anak kami autis." (partisipan 4)

"..... Yang mengganggu ya sangat mengganggu adalah orang suka menganggap anak kita ini ehh...dengan sebelah mata, menganggap anak kita tidak bisa berbuat apa-apa, dianggapnya anak kita seperti anak yang dalam tanda kutip tidak normal. Suka diasingkan dan diolokolok oleh teman yang normal." (partisipan 5)

Pernyataan di atas juga diperkuat oleh pendapat Mohr (2006) bahwa beban subjektif yang dirasakan oleh keluarga sebagai respons terhadap anggota keluarga yang mengalami autis ialah masalah rasa sedih dan perasaan negatif lainnya yang dialami.

\section{Beban Finansial}

Hasil penelitian menjelaskan lima dari enam partisipan mengungkapkan bahwa selama merawat anak autis satu partisipan mengalami kesulitan dari segi finansial. Hal ini merupakan beban bagi keluarga. Ketidaksesuaian antara kebutuhan dengan potensi yang dimiliki keluarga dipersepsikan keluarga menjadi beban dalam merawat anak autis. Hal ini dinyatakan partisipan karena untuk mendapatkan penyembuhan anak harus dibayar dengan sangat mahal dan untuk mendapatkan sarana kesehatan 
juga diperlukan biaya yang cukup mahal. Keterangan ini didukung oleh pendapat Mohr (2006) bahwa beban objektif adalah masalah yang berhubungan dengan pelaksanaan merawat anak autis, yang meliputi: sekolah khusus, makanan, transportasi, pengobatan, keuangan.

“... kesulitan yang kami alami yaitu dalam proses pengobatan untuk memperoleh kesembuhan bagi anak kami." (partisipan 3)

"... beban yang sering kami rasakan dalam merawat anak kami yang menderita penyakit autis terutama dalam hal biaya." (partisipan 2)

\section{Dukungan sosial}

Hasil penelitian didapatkan bahwa semua partisipan mengatakan dukungan yang diterima sebagai dukungan sosial yaitu perhatian yang diterima dari luar keluarga, informasi yang diterima dari luar keluarga, bantuan finansial yang di terima dari luar keluarga, dan bantuan keagamaan yang diterima dari masyarakat.

Bantuan perhatian dari luar keluarga

“... ada .... Puji Tuhan dukungan dari gereja, teman-teman yang selalu dukung dalam." (partisipan 2)

".... semangat atau support dan dukungan dari orang-orang yang peduli dan orangtua yang sama punya anak autism." (partisipan 1)

Bantuan informasi:

“... memberikan informasi tentang perkembangan anak autis dari keluarga besar" (partisipan 5)

“... mengajarkan anak seperti anak normal lainnya." (partisipan 4)

"... dukungan secara jasmani dan rohani dari kami sebagai orangtua dan keluarga." (partisipan 3)

“... bentuk dukungan tersebut berupa ikutnya dalam mengajarkan beberapa bidang keahlian untuk motorik halusnya dan dukungan tersebut dari keluarga (saudara)." (partisipan 5)

“.... Dengan menyekolahkannya, memberi HP dan komputer untuk belajar eh ... seperti kakak-kakaknya. Dukungannya dari suami, bapak, dan saudara-saudara lainnya." (partisipan 6)

Bantuan keagamaan

“.... Puji Tuhan dukungan dari gereja, teman-teman yang selalu dukung dalam doa." (partisipan 2)

Motivasi yang diterima oleh partisipan terutama saat partisipan merasa sedih dan tertekan. Keluarga menjadi tempat partisipan berkeluh kesah. Partisipan empat pernah menceritakan kesedihannya kepada tetangga. Nasihat atau saran yang diberikan tetangga partisipan dirasakan sangat membantu menurunkan perasaan sedih, kecewa.

Partisipan mengatakan kegiatan sekolah dapat memberikan bantuan kepadanya maupun anak autis untuk meringankan beban yang dialaminya dengan melakukan pendidikan sederhana tentang perawatan anak autis.

Dukungan yang diterima keluarga dalam hal ini sejalan dengan pendapat Friedman (1998) bahwa dukungan sosial yang meliputi jaringan kerja spontan dan informal, dukungan-dukungan terorganisasi non-tenaga kesehatan, dan dukungan terorganisasi dari tenaga kesehatan. Bentuk dukungan sosial yang diberikan adalah dukungan pemeliharaan dan emosi bagi anggota keluarga.

\section{Dukungan keluarga}

Dukungan keluarga sangat besar dibutuhkan oleh partisipan dalam merawat anak autis. Dukungan yang diterima semua partisipan berupa perhatian dari keluarga besar, bantuan finansial dan bantuan keagamaan. 
“... Dengan menyekolahkannya, mem... memberi HP dan komputer untuk belajar eh... seperti kakak-kakaknya. Dukungannya dari suami, bapak dan saudara-saudara lainnya." (partisipan 6)

".... Ada dong tentu, suami dan anakanak saya yang lain sangat sayang kepada anak saya yang spesial ini. Serta menerima keadaan anak eh...saya yang satu ini dengan seadil-adilnya." (partisipan 5)

“.... Ya dukungannya dari keluarga sendiri, karena itu pokok. Karena orang lain tidak ada yang mengerti, kalau diajak komunikasi nggak bisa, bergaul nggak bisa." (partisipan 6)

Hasil penelitian didapatkan yaitu menurut partisipan yang merawat, anak autis tetap menjadi bagian dari keluarga dan akan memengaruhi keluarga karena apabila di dalam keluarga terdapat satu orang anggota keluarga yang menderita sakit atau mempunyai masalah maka akan memengaruhi anggota keluarga yang lain. Dalam melaksanakan perannya merawat anak autis, partisipan dibantu oleh pihak keluarga (keluarga inti dan keluarga besar). Partisipan sangat memerlukan bantuan dari pihak lain karena selain merawat anggota keluarga yang mengalami autis, partisipan juga memiliki fungsi dan peran yang lain dalam rumah tangganya. Dukungan spiritual didapatkan partisipan melalui aktivitas berdoa. Partisipan mengatakan bahwa dari semua strategi koping yang dilakukan, melakukan aktivitas spiritual merupakan strategi koping yang paling mampu mengurangi beban psikologisnya.

Dukungan keluarga terhadap anak autis sangat berkaitan dengan fungsi suportif yang dikemukakan oleh Friedman (1998). Dukungan ini meliputi dukungan informasional, dukungan penilaian, dukungan instrumental, dan dukungan emosional. Hal ini juga sesuai dengan pernyataan Friedman (1998) yang mengatakan bahwa dukungan spiritual dapat membantu keluarga menoleransi adanya ketegangan yang kronis dan lama dalam keluarga.

5. Perhatian tanpa pamrih

Hasil penelitian terungkap bahwa partisipan dalam merawat mendapatkan dukungan dari keluarganya berupa uang atau materi, tetapi partisipan mendapatkan perlakuan yang kurang menyenangkan.

“.... Dengan menyekolahkannya, mem... memberi HP dan komputer untuk belajar eh...seperti kakak-kakaknya. Dukungannya dari suami, bapak, dan saudara-saudara lainnya." (partisipan 6)

“... doa, perhatian, kasih sayang." (partisipan 2)

“.... memberikan informasi tentang perkembangan anak autis istimewa, tetapi seperti anak normal." (partisipan 4)

".... dirangkul dengan penuh kasih sayang." (partisipan 5)

“.... bentuk dukungan tersebut berupa ikutnya dalam mengajarkan beberapa bidang keahlian untuk motorik halusnya dan dukungan tersebut dari keluarga (saudara)." (partisipan 5)

“.... Saya kurang telaten dalam merawat anak saya meskipun itu sudah diulang-ulang, pokoknya harus telaten mengajarkan untuk mandiri. Soalnya kan gak bisa nuntut lebih." (partisipan 1)

“.... Pengertian dan kesabaran serta keikhlasan dalam merawatnya. Itu yang sangat penting." (partisipan 6)

Menurut peneliti, dalam merawat anak autis pendampingan mutlak diberikan oleh keluarga karena penyandang autis memiliki gangguan berkomunikasi, interaksi sosial, serta aktivitas dan minat yang terbatas. Oleh karenanya perlu adanya proses pendampingan yang bertujuan memberikan motivasi kepada sang anak dalam mengembangkan karya mereka. Keluarga berupaya secara optimal memfasilitasi 
kemampuan anak autis, sebagai contoh bagi anak-anak berkebutuhan khusus ini, melukis bukan sekadar pemuas hobi. Lebih dari itu, melukis berfungsi sebagai terapi untuk melatih motorik si anak.

\section{Kecewa terhadap pemberi dukungan}

Hasil penelitian didapatkan pernyataan partisipan, yaitu partisipan dalam menerima bantuan baik dari masyarakat, tenaga kesehatan, maupun bantuan dari keluarga sering dihadapkan dengan sikap pemberi bantuan yang kurang menyenangkan sehingga kebanyakan partisipan merespons bantuan itu dengan rasa kecewa terhadap pemberi dukungan.

"... pengalaman yang sangat mengganggu hidup kami adalah lingkungan di mana kami tinggal tidak bisa menerima kondisi anak kami (autis)." (partisipan 4)

".... Yang mengganggu ya sangat mengganggu adalah orang suka menganggap anak kita ini ehh...dengan sebelah mata, menganggap anak kita tidak bisa berbuat apa-apa, dianggapnya anak kita seperti anak yang dalam tanda kutip tidak normal. Suka diasingkan dan diolokolok oleh teman yang normal." (partisipan 5)

".... tidak diterimanya keadaan anak tersebut di lingkungan keluarga besar." (partisipan 3)

\section{Takdir}

Hasil penelitian menyebutkan bahwa selama merawat anak autis, partisipan merasakan makna atau hikmah yang bisa dipetik dari semua kejadian baik yang menyenangkan maupun yang tidak menyenangkan. Partisipan dalam penelitian ini menjelaskan bahwa hikmah yang dirasakan lebih pada penerimaan terhadap takdir. Partisipan meyakini bahwa apa yang terjadi pada keluarga dan pasien adalah bentuk ujian dalam kehidupan dan selaku manusia kewajiban partisipan adalah terus meningkatkan kesabaran dan berusaha untuk mengatasi masalah yang dihadapi. Partisipan juga sangat berharap institusi maupun tenaga kesahatan, atau asosiasi maupun mitra pemerintah dapat membantu kesembuhan pasien, termasuk membuat pasien kooperatif terhadap proses pengobatan.

Hasil penelitian tersebut menunjukkan sifat altruistik yang dimiliki partisipan dalam merawat anggota keluarganya. Hal ini sesuai dengan penelitian yang dilakukan oleh Rhoades dan Mac Farland (1999). Rhoades dan Mac Farland (1999, dalam Asniar, 2007) mengungkapkan tiga makna yang dirasakan oleh keluarga yang merawat anggota keluarga dengan gangguan jiwa, yaitu altruistik yang ditujukan pada orang lain, aktualisasi diri yang ditujukan pada diri sendiri, dan tujuan eksistensial dalam hidup.

\section{SIMPULAN}

Pengalaman keluarga tentang beban dan sumber dukungan serta makna dan hikmah dalam merawat anak autis menunjukkan bahwa beban yang dihadapi partisipan dalam merawat adalah beban psikologi, finansial, dan masalah dalam pelayanan bagi anak autis. Beban psikologi yang dirasakan partisipan setelah merawat anak autis adalah perasaan sedih karena sikap anak yang tidak bisa mengungkap keinginan dengan baik dan rasa kecewa karena adanya stigma terhadap anak autis.

Beban finansial dirasakan oleh partisipan selama merawat anak autis karena tingginya biaya untuk mengikuti kegiatan keterampilan bagi anak autis. Untuk kebutuhan merawat anak autis, keluarga membutuhkan perhatian tanpa pamrih, perhatian yang tulus, serta bantuan dan informasi yang tulus.

Merawat anak autis membutuhkan beberapa dukungan yang diterima, yakni dukungan sosial dan dukungan keluarga. Dukungan berasal dari dalam keluarga 
maupun dari luar keluarga. Respons partisipan terhadap pemberi dukungan ialah merasa tidak puas karena masih adanya stigma yang masih suka membedakan dan memandang sebelah mata anak autis.

Makna dan hikmah yang dirasakan keluarga dalam merawat anak autis adalah sebagai takdir. Hal itu sesuai dengan pernyataan partisipan bahwa memiliki anak dengan autis merupakan cobaan dari Tuhan, mereka pasrah menerimanya, menjadi lebih sabar, dan melakukannya sebagai ibadah bagi Tuhan.

\section{DAFTAR PUSTAKA}

Agiananda, F. (2006). "Pengkajian, Beban, Kebutuhan dan Sumber Daya Keluarga dalam Merawat Penderita Skizofrenia (Sebuah Studi Kasus)". Tesis. FK UI. Tidak dipublikasikan.

Asniar. (2007). "Studi Fenomenologi terhadap Pengalaman Keluarga Merawat Anggota Keluarga Pasca Stroke di Rumah di Kelurahan Depok, Kecamatan Pancoran Mas, Kota Depok, Jawa Barat". Tesis. FIK UI. Tidak dipublikasikan

Creswell, J.W. (1998). Qualitative Inquiry and Research Design: Choosing among Five Tradition. Thousands Oaks: Sage publication, Inc.

Depkes RI (2008). "Riset Kesehatan Dasar". www.litbang.go.id. Diakses 10 Mei 2013.

Friedman. (1998). Keperawatan Keluarga Teori dan Praktek. Edisi 3. EGC. Jakarta Hamid, A,Y,S. (2009). Bunga Rampai Asuhan Keperawatan Kesehatan Jiwa. Jakarta: EGC.

Hamid, A.Y.S. (2008). Buku Ajar Riset Keperawatan: Konsep, Etika, \& Instrumentasi. Jakarta: EGC.

Happe, F. (2010). Autism an Introduction to Psychological Theory. London: UCL Press.

Hawari, D. (2001). Pendekatan Holistik pada Gangguan Jiwa Skizoprenia. Jakarta:
FKUI

Huzaemah. (2010). Kenali Autis Sejak Dini. Jakarta: Pustaka Populer Obor.

Irawan, P. (2006). Penelitian Kualitatif\&Kuantitatif untuk IImu-IImu Sosial. Depok: Departemen IImu Administrasi FISIP UI.

Kembaren, L. (2011). "Psikoedukasi Keluarga pada Pasien Skizofrenia". Jakarta: University of Indonesia, 2011. Disertasi.

Mamnu'ah. (2008). "Pengalaman Stress dan Strategi Koping Keluarga Merawat Anggota Keluarga yang Mengalami Skizofrenia di Yogyakarta: Studi Fenomenologi". Tesis FIK UI. Tidak dipublikasikan.

Mohr, W.K. (2006). Psychiatric Mental Health Nursing. $6^{\text {th }}$ ed. Philadelpia: Lipincott Williams Wilkins.

Moleong, Lexy J. (2010) Metodologi Penelitian Kualitatif. Bandung: Remaja Rosdakarya.

Murthy, S. (2003). Family Interventions and Empowerment as an Approach to Enhance Mental Health Resources in Developing Countries. Diambil dari www. pubmedcentral.nih.gov pada 14 Februari 2010.

Pamoedji. (2010). Pertanyaan dan Jawaban Seputar Autisme. Ciputat: Penerbit Hasanah.

Poerwandari, E.K. (2005). Pendekatan Kualitatif untuk Penelitian Perilaku Manusia. (Ed-3). Jakarta: Perfecta LPSPS, Fakultas Psikologi UI.

Polit, D.F. and Beck, C.T. (2004). Nursing Research: Priciples and Methods. 7 th edition. Philadelpia: Lipincott Williams \& Wilkins.

Potter, P.A. and Perry. A.G. (2005). Fundamental of Nursing: Concepts, Process and Pratice. (4 ${ }^{\text {th }}$ ed.) Philadelpia: Mosby-Years Book-Inc. 
Priyatna, A. (2011). Memahami, Mengasuh, dan Mendidik Anak Autis. Jakarta: PT Elex Media Komputindo.

Rahayu, M. K. (2011) "Pengalaman Hidup Orang Tua anak Penyandang Autis setelah Berhasil Diterapi di Sekolah Autis Kota Padang Tahun 2010.

Safaria, T. (2005). Autis: Pemahaman Baru untuk Hidup Bermakna Bagi Orangtua. Yogyakarta: Graha IImu.

Speziale, H.J.S and Carpenter, D.R. (2003). Qualitative Research in Nursing Advanceing the Humanistic Imperative.
Philadelpia: Lipincott Williams \& Wilkins. Stuart, G.W. and Laria, M.T. (2005). Principles and Practice of Psychiatric Nursing. $\left(7^{\text {th }}\right.$ ed). St. Louis: Mosby.

Sugiono. (2007). Metode Penelitian Kualitatif. (Ed.12). Bandung: Albeta.

Videbeck, S.L. (2008). Buku Ajar Keperawatan. Jakarta: EGC.

World Federation for Mental Health (2008). Learning About Schizophrenia: An International Mental Health Awareness Packet. http: http:///www.wfmh.org. Diakses 22 Januari 2010. 